\title{
Revolutionary Eruption in the Maghreb States of North Africa? A Discourse on Their Implications for United States - Africa Relations
}

\author{
Frank Enor ${ }^{1} \&$ Jide Chime ${ }^{2}$ \\ ${ }^{1}$ Department of History \& Int'l Studies, University of Calabar, Calabar, Nigeria \\ ${ }^{2}$ Department of Political Science, Enugu State University of Science \& Technology (ESUST), Enugu, Nigeria \\ Correspondence: Frank Enor, Department of History \& International Studies, University of Calabar, Calabar, \\ Nigeria. Tel: 234-806-360-2487. E-mail: enfrankie@yahoo.com
}

Received: September 12, 2012 Accepted: September 28, 2012 Online Published: February 26, 2013

doi:10.5539/jpl.v6n1p163

URL: http://dx.doi.org/10.5539/jpl.v6n1p163

\begin{abstract}
Revolutionary uprisings which engulfed states of North Africa between December, 2010 to October, 2011 were interpreted by the West simply as resulting from "lack of economic opportunities" in the region and the "iron fist" policy of their rulers. These interpretations, as contended by this paper are too simplistic and grossly inadequate to deepen understanding of the issues which have their antecedents in the policies of the Superpowers during the Cold War years. The Cold War polarized the world into two blocs thereby creating client-states and shoring-up despotic regimes with deficient national aspirations at the expense of their working masses. The paper maintains that the Arab Spring is partly the result of a turning point in Western diplomatic encounters with the non-European World of Africa, and Asia on one hand, and the insensitivity of leadership in client-states on the other.
\end{abstract}

Keywords: revolution, Maghreb, uprising, policy, African independence, cold war, despotic regimes

\section{Introduction}

Between December, 2010 and October 2011, socio-economic and political upheavals erupted in the Maghreb region of North Africa and the Middle East in a manner which some have described as proportionate to a wind of change blowing across the region. These uprisings which took place in explosive rapidity have been termed as 'revolutions' either for want of a better nomenclature or resulting from the revolutionary propensity which they assumed. At the end of the upheavals, the governments of three Maghreb states- Tunisia, Egypt and Libya were torpedoed and replaced not with revolutionary regimes but with either Transitional Councils, military juntas or elected governments superintended by the military as in the case of Egypt.

Resulting from faulty assumptions, the West have blamed autocrats of the region for the uprisings and further attributed the upheavals to a lack of economic opportunities. At the wake of the 'revolutions', the US intervened ( in the case of Libya), under the auspices of UN, purportedly for humanitarian considerations. This paper recalls that earlier invasions by the West purported to be for the same reasons only ended up in the balkanization of African states into 'spheres of influence', to secure markets and raw materials. Predatory interventions of World Powers on smaller nations for strategic concerns without commensurate returns sharpen the contradictions between the ruling class and the masses who perceive their rulers to be collaborators with the very forces of imperialism. Having been impoverished and alienated from the products of their labour, the working class and 'peasants' become agitated and restive, especially when socio-economic conditions become unbearable. Until capitalism bridges the gap between the ruling class, and the 'hungry', uprisings of revolutionary proportion may not cease and this is a concern as it is important to international peace and security. The ruling class in Africa should learn from the bitter fact that the advance industrial nations are working assiduously to bridge the gap between their rich and the poor as a 'safety measure', to secure their property. This can be explained by the massive outflow of Western Capital looking for investment outlets in profitable areas of the World. In the face of competition for strategic resources coming from China and other emerging Asian economies, the West may have to fine tune their diplomatic and trade policies with Africa or lose its influence in these nations. 


\subsection{Material Studied}

Materials for this paper were essentially derived from a selection of published literature on United States foreign policy and US-Africa Relations, internet sources, newspapers/magazines and historical literature on the region some of which are reflected in works cited.

\subsection{Area Description}

The area is the North Africa sub-region bounded by the Mediterranean coast to the North, the Atlantic Sea board to the west, the Sahara Desert and the West African States to the south. The Red Sea forms the eastern border. Technically, Egypt is not considered part of the Maghreb states, but has been generally referred to in this work as a result of the revolution in the region.

\subsection{Methods and or Techniques}

The method adopted for this paper is basically historical and descriptive. The paper does not pretend to test any hypothesis other than the general assumptions gathered from the literature as follows:

(i) US Foreign Policy expresses its core values to the seeming detriment of the aspirations of developing countries especially since 1945 to 1990.

(ii) The ideologization of US Foreign Policy since the Cold War neglected, denied or destabilized younger nations which propagated independent paths to progress.

(iii) US Foreign Policy has set itself a target of militant Islamic groups

\section{The Maghreb Region of North Africa}

The Maghreb is a term that has been used to refer to Morocco, Algeria, Tunisia and Libya. At the opening years of the $19^{\text {th }}$ century, two administrative systems were elaborated in the Maghreb; one was the independent Maghreb under the Sherifian dynasty of the Alawites founded in 1649; the other were the semi-independent administrations of the Regencies of Algeria, Tunisia and Libya under the effette suzerainty of the Sultan of Turkey (Ayandele, 1966). In Morocco, a centralized politico-administrative system under the monarchy held sway for several centuries. The monarchy came to be a very significant institution in welding together the bellicose Berber inhabitants of the region.

For politically, the Sanhaja Berbers, the Masmuda, and Zenata groups living in the country of disobedience (Bilade es Siba) eschewed any form of centralization and would not transfer their loyalty to any unit larger than the clan except when threatened by an external aggressor. Spiritual qualification and military power assisted the Sultan greatly in commanding obedience of the Berber-Arab population in specific cases. Rebellion was a genetic characteristic of the Berber-Arab

On the semi-independent administration of Algeria, Tunisia and Libya which lacked a centralized monarchy of the Sherifian type, the situation was less stable. Algeria was administered form Turkey and Tunisia alike. Libya had established itself independent of the Turks since 1711 and was being administered by Karamanli dynasty.

Emmanuel Ayandele, a Professor of history (emeritus) (1966) had remarked that "internal political weakness and the fissiparous tendencies in the Maghreb notwithstanding, all the governments were sovereign vis a vis the European Powers". In fact, the Maghreb States or "Barbary Corsairs" and some European countries had indulged in mutually beneficial piracy on the Mediterranean waters for centuries. The records of the times show clearly that the Maghreb states established piratical superiority over the Europeans to a point where they captured Europeans as slaves and compelled them to erect their palaces, till their land and row their galleys; a situation which contrasted with that in the Atlantic Seaboard of West Africa. (Ayandele, 1966).

From the 1800 onwards, European and American powers began to repudiate the sovereignty being exercised over their nationals by the Sultans' of the Maghreb states. The usual practice of paying tribute, "buying immunity", to the Maghreb chieftains was no longer palatable. The foreign powers resorted to bombarding their coast, or supporting rival claimants to the throne. This undermining of the sovereignty of the Maghreb rulers by European powers, writes Ayandele, "was a manifestation of European economic imperialism in Mediterranean Africa".

By 1900, the Maghreb region had been balkanized into different European spheres of influences beginning with Algeria by France in 1830, Morocco in 1904; Tunisia in 1883 and Libya by Italy in 1911. The United States was never a "scrambling power" in Africa outside her involvement in 1789, when it checkmated the Barbary States of pirates who operated from bases on the Mediterranean Coast. In obedience to the Munroe Doctrine of 1823, the US never interfered with European Colonies without differing to the Metropolitan power. As elsewhere in 
Africa, US initial intention was to remain passive in the affairs of North Africa until the Second World War (1939-1945) exposed the geostrategic and economic importance of the region to the US' national interest. British and French involvement in the affairs of North Africa cannot be undermined but being part of the Arab World; developments in North Africa often undermined US position in the Middle East. US main interest and concern in the Maghreb therefore was to checkmate communist insurgency and this became synonymous with preventing radical nationalist groups from coming to power. In 1954 the CIA cautioned that the US could no longer afford to remain passive in the affairs of the region or its prestige in the Third World would suffer and her bases in Morocco may be endangered (Kolko, 1988). It was from this and other calculations that the US tilted slightly to support more self-government in Morocco and Tunisia within the framework of French hegemony, and further intensified and maintained friendly relations with some North African States (excluding Libya) and those of the Middle East, all of winch are going through revolutionary upheavals. The revolutions so called would now be examined.

\section{The Revolution in the Maghreb from Point of Theory}

The term 'revolution', has been defined from varying points of theory and by revolutionaries and non-revolutionaries alike. My purpose in this segment is not to hold the audience down to the many definitions of revolutions but to test the validity of the revolutionary postulations of the "Masters" (Karl Marx, 1818-1883; V. I. Lenin, 1870-1924), on the African soil for; as far as the left wing Marxist are concerned, any theory of revolution which overlooks the contradiction between the forces of production and the relations of production does not well understand the dynamics of society's development.

For Amilcar Cabral,

National liberation and social revolution are not exportable commodities, they are and increasingly so every day, the outcome of local and national elaboration, more or less influenced by external factors (be they favourable or unfavorable) but essentially determined and formed by the historical reality of each people and carried to success by the overcoming or correct solution to the internal contradictions between the various categories characterizing this reality (Cabral, 1966).

Michael S. Kimmel (1990) has stated that a theory of revolution must address five basic questions as follows:

(i)

What is a revolution

(iii)

What causes revolutions

(iv) Why do people participate in revolution, and finally

(v) What are the consequences of revolution?

How these questions are answered, according to Kimmel, will determine their ability in explaining historical cases of revolution and their comparability as sociological theories (Kimmel, 1990).

Having erected this platform, the Marxist theories of revolution can now be tested against the Arab spring.

Social revolutions express a general law of transition from one economic formation to another. Henecle (1966) expressed this bias when he stated that the essence of life is change and motion; for life cannot be static, it should be perpetually in motion; motion involves contradiction, and without contradiction there is no progress. From the Marxist viewpoint therefore, revolution is a process of resolving the major socio-political and socio-economic contradictions that have developed in a given society. They are the peak of class struggles of the oppressed against their oppressors, a conscious historical activity of the masses which brings about a change in the production relations leading to a new class in a position of dominance. The Marxist, who base their perception of revolutions from their observation of the class character of the capitalist mode of production, postulate that the capitalist produce for exchange and profit; this mode is not fixed, it is transient; sooner or later it will give way to a socialist mode of production where the producers of the goods overthrow the property class. The socialist society so created evolves into a communist society. For Karl Marx, revolution occurs when the object conditions necessary for them have developed.

According to the analyses, society is held together by a dynamic tension between the means of production and the relations of production, which consist of that social arrangement that group of men and women developed by which to organize the provision of the necessities of life. The process of production is social, yet the means of production have been privately controlled or owned thus dividing society into two classes of those who own the means of production and those who own nothing other than their labour power. The fact that production is privately owned impels their development to proceed at different rates. The means of production develops more rapidly than the relations of production and at certain moments, productive forces develop so fast that the 
existing relations of production can no longer keep pace with the changes within the existing social framework. Contradictions set in at this moment and social revolutions are experienced.

In other words, revolutions are the result of the development of insoluble contradictions within society which prepares the way for social crisis which burst out in political revolutions. With a change in the economic foundation of society, the entire immense super structure is more or less rapidly transformed. The class struggle model of explanation was forcefully presented by V. I Lenin who defined revolution as:

the passing of state power from one class to another is the first, the main, the basic principle of revolution, both in the strictly scientific and in the practical political meaning of that term (Kimmel, 1990).

To Lenin, a revolutionary situation is caused by the decay and collapse of a ruling class and the simultaneous anger of the oppressed class. Moribund policies of the ruling class will always cause fissures through which the discontent and indignation of the oppressed classes burst forth. When the working class revolt, they seize the state apparatus, transforming irrevocably the class character of the society.

Marx and Lenin appear consistent on the centrality of class as the determinant cause of revolution; however, there are significant departures between them. For Marx, the misery of the oppressed class is a crucial factor in bringing about revolution. For Lenin, revolution occurs not when the ruling class is succeeding but when it has failed, when its collapse has begun and it is scrambling to reconstitute its rule and deploy the repressive apparatus of the state to maintain its domination of the society. Lenin also differs from Marx in his emphasis on the centrality of political parties in the process of revolution. While Marx believes in the spontaneity of the working class in ushering in the revolution, Lenin does not believe in the spontaneity of revolution. He rather argues that revolutions are carefully planned political event. Lenin argues that trusting the working class will be a tactical error because left to themselves, that class would not progress to a revolutionary class consciousness that will incite revolution. Rather, the working class needs to be led by a vanguard political party- a group of dedicated revolutionaries who are able to discern the opportunity for revolutionary activity even in the absence of a conserted revolutionary movement among working class. The working class, according to Lenin, will only develop "trade union consciousness", a consciousness that will promote their immediate economic wellbeing. The presence of the vanguard political party will push the working class to articulate political claims, and that will transform the narrow economic concern of the working class into visionary activity of a revolutionary class.

The usefulness of Marxism-Leninism as theories on societies development have been in a nutshell summed up by Mao Tse Tsung as follows:

Universal truth of dialectical materialism, which is not dogma but a guide to action... being determines consciousness, that the objective realities of class struggle and national struggle determine our thoughts and feelings (Gurley, 1988).

The Marxist theory of revolution no doubt, a scholarly formulation on how society transits from one stage to the other may not be well equipped to confront (explain), the revolutionary situation in the Third World. The obvious truth that Third World societies are not 'factory based' only point to the uniqueness of societies and the "historical realities of each people". Revolutions so called in the Third World have been linked to nationalism and national issues and largely based on mass (peasant) revolutionary movements as experienced in the Maghreb recently. The elevation of the peasantry into the chief revolutionary actors is the development of socialist societies as exemplified in $20^{\text {th }}$ century revolutions in Russia, Cuba, and China and so on. While it may be correct to state that the Maghreb uprising which assumed revolutionary momentum exposed the structural content and therefore causes of the upheavals, it cannot be said that those revolutions followed the class theory of the Marxist. One may add perhaps that it was the lack of a theoretical bases and the absence of a vanguard party that Maghreb uprising does not qualify to be called revolutions in the Marxist tradition.

However, here and there one still finds some coloration of the type found in social revolutions of the 20th century. A coalition of social forces, mass discontent of unemployed youths, skilled and unskilled artisans, a vociferous intelligentsia, a working class that has been conscientized by trade unionism, the media and foreign influences all may have provided the revolutionary content which dislodged North African autocrats from their pinnacle of power.

In a sense therefore, it can be argued that the socio-political upheavals of the Maghreb which assumed revolutionary proportion and sweeping across North Africa and the Middle East with explosive rapidity have not translated their societies into their dreams and therefore not revolutionary. For as would be expected, a revolution can be a complete overthrow of the established government in any country or state by those who are 
previously subject to it. This implies that revolutions must replace the rulers or government, they must be complete and successful to be called revolutions and the new ruler must have a social agenda with revolutionary transformation of society.

Much of what emerges in the Maghreb in the years to come are regime change as none of the so called revolutions in North Africa succeeded in raising the structural foundation of society. Some of the uprisings (Libya) were already neutralized of their revolutionary content having been hijacked, infiltrated or cornered.

Hannah Arendt can speak of a revolution only when change occurs in the course of a new beginning, where violence is being used to constitute a different form of government, to bring about the formation of a new body politic, where oppression is eliminated and society is free. From Arendt's view point, revolution differs from other forms of social change like coups, rebellion or revolt which in some cases could lead to revolution. According to Arendt, rebellion talks about "liberation", whereas revolution is the foundation of freedom (Kimmel, 1990). This segment will be anchored with the postulation of Kimmel (1990) that a model of revolution must analyze three spatial relationships: the international context, class relations at the level of production and political relationships among various classes and the state. These three, posited Kimmel, are the fabric which a revolution can be built.

\section{Factors in the Uprising}

The recent uprisings in the Maghreb have been explained simply as resulting from the "iron fist" policies of the dictators of those countries and the lack of economic opportunities in the region. These explanations by the West raise a lot of problems for historiography. Outside being too simplistic, Western interpretations of the events in the Maghreb are not only grossly inadequate to deepen understanding of the issues involved, it fails to address the issue of causation. To understand causation, pertaining to the revolutions in the Maghreb, it is pertinent to distinguish between the long run structural causes from the short run events that set these structures in motion and the immediate historical event that ignite the conflict. This is important because revolutions do not just happen because of economic crisis; religious crisis and or political crisis even though all of these are causative factors. Contrary to Karl Marx's 'spontaneity' of the working class, in ushering the revolution, revolutions take their roots in the society's past and they come when the objective conditions necessary for them are ready. The mistake of interpreting the immediate cause as the structural cause of the revolution may mislead one to proffering haphazard or wrong solutions to the issues raised.

The Maghreb revolutions were local with external factors laying the tap root for the 2010-2011 uprisings. To understand this, it is pertinent to consider the Arab Spring as partly an expression of the many years of bottled-up emotions, aspirations and deprivations in socio-political and economic spheres of life which insensitive leadership glossed over in defense of narrow neoliberal policies. Dwindling economic fortunes and the lack of opportunity to freely determine their leaders by the franchise received a boost when the unemployed young Tunisian immolated himself. This incident set in motion the wind of change which blew rapidly across the Arab world from Maghreb, North Africa to the Middle East. With the coalition of social forces in the different states, they dream to carry their destinies in their hands in a democratic setting where their aspirations can be fulfilled. On the other hand, is the deeper explanation which has its roots from the Cold War.

The Cold War between the US and the USSR after 1945 polarized the world into two rival blocs with client states as testing grounds for rival ideologies and arsenals'. In North Africa, the US has reorganized its earlier passive posture to a more proactive engagement with states like Egypt, Morocco and Tunisia which became bulwark states against Soviet communism and Libya essentially. The US feared that Libya is being used by the Soviets' as a base for positioning Soviet weapons which could be used in the Middle East when occasion demands (Kolko, 1988). This fear became obvious when Colonel Muamar Qaddaffi came to power in 1969 and expelled American and British forces and closed down their bases. In the Middle East, US allies included Bahrain, Jordan, Saudi Arabia, Yemen and Israel. The radical posture of Qaddaffi is said to be responsible for reshaping US-Africa policy and the Middle East in response to the activities of USSR. In other words, states of North Africa and the Middle East which currently experienced revolutionary uprisings were allies of the superpowers during the Cold War. In spite of the undemocratic and repressive leadership styles especially in domestic policies, these corrupt regimes were condoned by their international godfathers. Superpowers' policies in North Africa and the Middle East were determined by the advantages or otherwise they brought to the US or USSR and not how policies affected the welfare of the citizens of those regions. Both superpowers were handy to assist their client states suppress internal uprisings or popular demand for good governance in order to prevent each other from exploiting such uprisings to its advantage. These regimes maintained their legitimacy and longevity to a manner prescribed by their international allies rather than respond to the immediate needs of 
development. The allies on the other hand maintained a blind eye to the domestic excesses of their satellite states.

Egypt for instance was the most important Cold War ally of the US in North Africa. Egypt receives 1 billion dollars annually from the US to fight against Islamic Organizations. Relations with the US have been very cordial to the eve of the overthrow of Hosni Mubarak. The US has been a solid supporter of President Ben Ali of Tunisia until his deposition in January 14, 2011. It should not be surprising therefore that the US did not poise for military intervention in these two North African States. In the case of Libya, which has been a 'terrorist' state by US definition, military option was adopted for 'humanitarian reasons'. A plausible interpretation of the Maghreb uprising should be that the autocrats in the regions are harvesting the fruits of their foreign policies with the Superpowers. It is from this background that the Maghreb uprising can be understood.

On a general note, in consideration of the timing of the revolutions it would be fair to say that the uprisings are part of a global financial crisis and its consequences on human and material development. Increasing cost of food prices, mass unemployment, poverty and the inability of national governments to proffer solutions to these challenges provide objective causes of the uprisings. When specific local issues combine with global financial pressures to bubble to the surface having been suppressed for a long time by their autocratic regimes, any event such as the event of December 2010, in Tunisia can ignite a bon fire leading to a revolution. The Maghreb uprisings were therefore not a sudden event triggered by the immolation of Mohammed Buoazizi (immediate cause), it was an accumulation of a concatenations of events traced to the Cold War years.

\section{Western Intervention and the Poverty of US-Africa Policy}

In the wake of North Africa 'revolutions', the US President, Barrack Obama at the State Department declared in a speech that positioned the United States and its values behind the democratic uprisings. According to Obama:

Across the region, those rights that we take for granted are being claimed with joy by those who are prying loose the grip of an iron fist,... our own nation was founded through a rebellion against an empire (Obama, 2011).

The US supported the democratic aspiration of the people of Tunisia, even when it has been a solid supporter of Ben Ali until he was ousted. The President announced steps by the US to cancel a billion dollars worth of Egyptian and Tunisian debt, establish an Egyptian-American private enterprise fund and guarantee up to a billion dollars in borrowing through the US Overseas Private Investment Corporation, a US agency that mobilizes private sector investment in new and emerging markets (Enor, 2012).

On Libya, Obama reiterated his position that the US and its NATO allies were right to intervene militarily to prevent an imminent massacre of thousands of opposition rebels.

When Qaddaffi inevitably leaves or is forced from power, decades of provocation will come to end, and the transition to a democratic Libya can proceed (Obama, 2011).

Obama's speech did not mention Saudi Arabia, which has close ties to the US, and a major oil supplier and home to several of the 9/11 hijackers. Saudi Arabia has a high record of human rights abuses yet ranks very high in US National interest. It is this poverty in US-African policy that this segments attempts to dwell however brief.

US-African policy can better be understood as a continuation or better still a diplomatic representation of Western economic imperialism of the $19^{\text {th }}$ century. As the United States was not a "scrambling power" in Africa, developments after the Second World War (1939-1945) put it in a superpower position to dictate the direction and dynamics of international affairs. The Marshall Plan and the Truman's Doctrine enunciated by President Harry S. Truman (1945-1953) were not only economic and military packages for Western European economic reconstruction; they were also strategic and political to put off USSR as well as communism outside the NATO states (Enor, 2012).

Unfortunately for Africa, poor and green in international politics, it did not qualify for a Marshall Plan for the mere reason that it was not a 'danger zone'. "There was no compelling ideological danger in Africa to justify a Marshall Plan". In other words, US attention, assistance and cooperation went to areas or client-states that were in the orbit of international capitalism. African states which pursued independent paths or had socialist leanings like Angola, Libya, Mozambique, Congo (under Lumumba), and Somalia were either neglected or destabilize. US national interest focused on Africa's raw materials, strategic naval bases, communication lines and client states which toed the capitalist path and could be used to checkmate or destabilized neighbouring states which refused to embrace the capitalist mode of production as their development strategy. These and many more policy 'inconsistencies', blunders and selective engagement made the US the target of Islamic militant groups, and bitter criticism from analyst and other sympathetic proponents of a human face diplomatic relations. 
America, in the eyes of Tom Mboya was a symbol of anti-colonialism but when it turned its back from championing the cause of the colonial peoples as a result of its Western alliance, Africa was thrown into puzzled disappointment. On the situation of acute immorality of the racist regime in South Africa, America maintained its economic interest with support for South Africa and military support for Portugal until the coup of 1974.

Ali Mazrui (1977) has concluded that America had done fewer bad things in Africa than she had done in Asia and Latin America. She has also done fewer good things in Africa than elsewhere. The revolutionary principle by which America was known for have been inactive in Africa compared to Latin America and South East Asia. Her sins in Africa, according to Mazrui, have been those of "indifference" and caution, of "insensitivity" and moral distance (Mazrui, 1977).

US- Africa relations has been guided by anti-communism and this has not assisted Africa remarkably neither did the policy resolve Cold War issues. Even after the Cold War, it must not be supposed that the neo-liberal position of the US is a remarkable departure from Cold War foreign policy. In assessing US-Africa policy in the 'New Partnership' therefore, one should be cautious to discern mesmerizing rhetoric from the actual performance on the ground.

The Clinton administration (1993-2001) began the efforts to look at Africa from a broad perspective rather than a selective case-by-case approach. The African Growth and Opportunity Act (AGOA) came into being to drive home this new policy. Clinton's administration also pursued a two-pronged strategy to increase the importance of Africa as a trading and strategic partner. First, promoting economic development, democracy, respect for human rights, and conflict prevention and resolution as a way to reinforce Africa's dependency on the global economy. Secondly, the US sought to address security threats emanating from Africa, including terrorism, drug trafficking and illicit arms (Enor, 2012). Incidentally, after the failure of "Operation Restore Hope" in Somalia in 1993, America recoiled to a multi-lateral approach to regional and international conflicts as recent action in Libya has shown. The question that emerges from US recent involvement in the Maghreb Uprising is; why did the US prefer a military approach to the Libyan uprisings and was passive in developments in Tunisia and Egypt? Secondly, the invocation of resolutions 1970 and 1973 which enforced no fly zone over Libya has been widely criticized as unprecedented and different from UN past reactions to other freedom seeking movements.

The imposition of a no-fly zone over Libya has been sold as a "humanitarian" military intervention to attempt to stop Libyan dictator Muammar Qaddaffi's bloody slaughter of the rebels who were cornered in the eastern city of Benghazi. President Obama defended US involvement in the operation as being taken to avoid a massacre that would have "stained the conscience of the world". These half-truths are not only misleading, they are a distortion of African historiography. Earlier, European imperial adventurisms have been posited to be undertaken for humanitarian considerations. These half-truths are dangerous and conceal the very intention of white predatory interventions. The multi-lateral military action on Libya represents and opportunistic ploy by the imperial powers to defend their strategic and economic interest in the region. Revolutionary uprising in Libya, would not be in the interest of the West. Libya's oil reserves as well as it geopolitical position and role in "influence equation of big international powers", is a more plausible reason for the special approach of the Security Council to Libya. The General Assembly was also apathetic towards Tunisia and Egypt but was active in Libya as in suspending Libya in the Human Rights Council. The military option on Libya was a way to reassert their power in the region, hijack, or truncate the revolutionary momentum of the Libyan people and possibly implant a pro-western regime. Or how else could the US remain silent to the bloody massacre carried out in Bahrain by Saudi Arabia and Pakistani mercenaries-this particular carnage favours their interest in the region. The US closed its eyes to the dismal corruption, and bad governance of their puppet regimes in a bid not to endanger their objectives in those regions. Its short-sighted strategy of "buying stability" while turning a blind eye to repression, according to observers reveals the shallowness of its democratic values. Its "democracy international" has been criticized as a ploy for making the world safe for Western Capital. It is little wonder therefore that in their bid to enthrone this imported brand of democracy, emerging democracies in Africa have resorted to a caricature and simulacrum of a phony democracy. An occidental brand of bourgeois democracy which cannot guarantee transparency, accountability, good governance and the pursuit of happiness is only sharpening the productive force for obvious contradictions with the relations of production.

There has been so much orchestra of good intentions than the actual practice. "Democracy", "Health", "Security" and "opportunity", laudable and critical as these four areas may be to the future of this continent. Africa, for all its worth and strategic significance to the world economy deserve more than tantalizing rhetorics. At a time when China is challenging the hegemony of the US and its Western European allies in the competition for World resources, and the North African states feverishly replacing their dictators with Islamic leaders, one would not need any oracle to imagine what future relations between Africa and the US would be if America does 
not work fast to fine tune her policies in Africa and other regions of the world. To these issues, the last segment of this paper has been dedicated.

\section{Maghreb Uprisings and Their Implication for US-Africa Relations}

If as it is argued that US Policy in the Maghreb was to maintain autocrats as a check on militant Islamic insurgents, in the Sub-Saharan Africa, policy has not radically changed from the neoliberal strategic encounters with vital interest as the corner stone (Rothchild \& Keller, 2006). This position has been furthered essentially by the Republicans who define Africa as fitting into their economic interest hence the promotion of free trade. The Democrats have demonstrated a broader outlook on Sub-Saharan Africa since 2000AD. With the AGOA, trade and investment, assistance and advisory roles, promotion of good governance, health and education has been furthered for the interest of the region and America

Maghreb uprisings have implication for Africa on one hand and far reaching implications on US-Africa relations on the other. The insensitivity of African leadership class to addressing the basic needs of their citizens compounded by the undeniable facts that this class allows itself to be used as puppets, collaborators and proxies of the superpowers or the advanced industrial nations can only be explained from two angles. The lack of understanding of the meaning of African independence and the ideological deficiency of the leadership class. These two factors constitutes the greatest weakness of the struggle against imperialism.

As Marx and Engels observed, the ruling ideas of any age, are the ideas of the ruling class:

Where a ruling class has sold the birthright of its nation to a virulent if decadent imperialism, the nationalism it espouses can only have the status of a shroud (Wilmot, 1980)

Dr. Amilcar Cabral (1966) referred to this struggle against "our own weakness" when he succinctly stated that:

The ideological deficiency, not to say a total lack of ideology, within the national liberation movements...which is basically due to ignorance of the historical reality which those movements claim to transform...constitutes one of the greatest weaknesses of our struggle against imperialism, if not the greatest weakness of all... (Cabral, 1966).

Ignorance of the historical reality and meaning of African independence has continued to plague the continent with dangerous consequences to the future of Africa. "Despite the granting of independence", writes, Patrick Wilmot:

African countries, due precisely to their lack of ideological clarity still foster the colonial point of reference by their dependence on the intellectual products of Western imperialism from which they claim to have liberated themselves. They allow the consciousness of their youth to be shaped by forces inimical to African nationalism... (Wilmot, 1980).

"A genuine African ideology", "one which seeks to understand and transform the historical realities of African struggle for survival in the modern world", according to Wilmot, "cannot afford the luxuries of idealism, Machiavellianism,... it must be a concrete reflection of this reality, in all its temporal dimensions... African nationalism must recognize that all the peoples of Africa share the same historical destiny... the very survival of every African, is a condition for the freedom and survival of every other".

In the bid to free itself from the sins of ideological deficiency, some if not all African states resort to what Professor Claude Ake has termed defensive radicalism - "an attempt at mystification"; the assumption of a radical posture as a cover for containing revolutionary pressures and for maintaining the status-quo. According to Ake, as the ruling class of Africa cannot rely exclusively on force to maintain their rule, defensive radicalism becomes the only alternative to force; and the only way of connecting with the aspiration of the masses. To join the struggle or pretend to identify on the side of the masses, one must necessarily be progressive and hold progressive ideas (Ake, 1978).

The failure of military options and multi-national approaches to international conflicts as spearheaded by the US in Afghanistan, Iraq and now Libya only point to regional and continental options to international conflict resolutions superintended by the United Nations, as a departure from failed experiments. The unity of all African states with primordial interest and loyalties to the African Union (AU), holds the key against the predatory interventions of World powers who dominate the UN. This type of unity can only be founded on a solid ideological fulcrum which is currently lacking in the continent. This view point is not new, it has been expressed in the 1980's by patriots like Wilmot when he noted graphically that:

African unity represents the combination, coordination and articulation of power on a continental scale... with Pan African unity, Africa can catch up with an even surpass the established centres of 
global power... without Pan African unity the continent will remain what it is today, a laughing stock in the international community, taken seriously by no one least of all by African leaders themselves (Wilmot, p9).

The dreams of statesmen like Osagyejo Kwame Nkrumah, Patrice Lumumba, Nwalimu Julius Nyerere, Samora Maschel, Nnamdi Azikiwe among others, should inspire a proactive African Union with its cousins NEPAD, to a continental brotherhood in all aspects of development as an alternative to basking and chasing the "rays of Occidentalism" which earlier statesmen had cautioned against. Leaders who owe their legitimacy to foreign powers, cannot claim to be independent. African independence is hollow until it translates into real, improvement in the conditions of life" if the leadership of African states look inwards, they resist the temptation of being collaborators with imperial factotums who mimic Africa's hard earned independence and cause their leaders to unleash misery and lack on their citizens in the midst of plenty. The paradox of this situation is captured by Professor Osita Eze and represented as follows:

While Africa's significance on the global market is minimal in terms of production and its very position in the world is precarious and contested, it is at the same time, the supplier of strategic and critical resources, that are needed by the global economy for continued growth. The second major paradox is that despite the continent's abundant resources, Africa remains the poorest continent in the world... (Eze, 2010).

Indeed, African nationalism cannot be taken seriously neither would it be given the respect which her wealth of human and natural resources deserves until it takes the bold act in reaffirming the legitimacy of Africa's historic interest as Nigeria General Murtala Mohammad did when he openly confronted imperialism in Angola. The late General Murtala Mohammad affirmed the existence of a well-defined African interest that was primal and inalienable. According to him:

The time has come when we should make it clear that we can decide for ourselves; that we know our interest and how to protect those interest; that we are capable of resolving African problems without presumptuous lessons in ideological dangers which, more often than not, have no relevance for us, nor for the problem at hand (Wilmot, 1980, p.9).

African leaders cannot continue to be beggarly in their foreign policies. The years of enslavement and colonialism which brutalized Africa and rendered it poor and inferior before the international community are since over. Africa cannot continue to play to the gallery fifty years after it was granted political independence for in the words of President Olusegun Obasanjo:

African countries are today independent and hold the levers of progress largely in their own hands (Obasanjo, 2010).

This fact I supposed is informed by the many strategic mineral and agricultural resources of the continent, many of which have not been fully tapped. These resources, combined with a large market provides the bases for which China and other emerging economies from the Asian continent are in a cut-throat competition with the "old European powers" and the US in what has been termed the new scramble for Africa (Eze and Anigbo; 2010).

Orientalism is fast replacing occidentalism as manifested by the pervasive chinazation of the Nigerian economy (Enor, 2012), only time shall tell the consequences of this uncritical and open ended invitation to foreign direct investment on the Nigerian economy. Rather than wish away its strategic resources, Africa should seize this golden moment to redefine the lopsided and unequal trading arrangements which serves to develop the centre at the detriment of the periphery in this organic relationship brought to being by the incorporation, internationalization and globalization of mono-cultural economies. The quest for NIEO will fall on deaf ears until Africa learns to guard its resources and markets jealousy and utilized them maximally to drive home socio-economic development. If the advanced economies which drive foreign direct investment still protect their home industries even when they canvass for free trade, Africa should do no less.

The US can no longer continue to relate with Africa from its cold war policies, for as these analyses have shown, cold war global policy did not further Africa's development in any remarkable way. Even in the "New Partnership", that started the 1990s, much has been recorded, but so much remains to be done in the areas of security, the fight against corruption, fake drugs, health and other areas essential to life and happiness. The US should match rhetoric with concrete actions and in fact initiate a "Marshall Plan" for Africa or it would loose out completely from its geopolitical involvement. At a time when Islamic regimes are taking over the reins of leadership of the Maghreb states and the Asian Tigers taking over the markets and resources of Africa, the US 
and the West have a very urgent task of rebuilding and fine toning their foreign policies with Africa and the Asian states of the Middle East or lose its prestige and friends in the Third World.

\section{Conclusions}

This article has examined the Maghreb revolutions against the backdrop of their implications for US-Africa relations. The paper has taken a theoretical approach to the analyses of revolutions with a firm conviction that the revolutions in the Maghreb wear the colour of Marxist-Leninist theoretical assumptions but lacking in some basic ingredients. For the core Marxist, for a revolution to take place, objective conditions must coincide with subjective factors some of which are ideological orientation of the masses and a revolutionary vanguard among others. Maghreb revolutions lend credence to the fact that Third World revolutions have a character of their own. Multinational military intervention in international conflicts have so far not resolved those conflicts, a regional and continental approach to international conflicts, this paper opines, should be a wonderful departure from failed experiments. This position can only gain currency when African states redefine their independence backed by an ideology. When this happens, the fallacy and inadequacy of Western values and predatory interventions in the Third World would no longer sell. In the face of competition from China for strategic resources and Islamic regimes assuming the reins of power in the Maghreb, the US has the urgent need to fine tone her foreign policies with Africa and the Middle East states or lose her prestige and face more provocations from militant Islamic regimes.

\section{References}

Ake, C. (1976). Revolutionary Pressures in Africa. London: Zed Press.

Allen, J. V. (2001). Who will Teach About Africa? A Personal View. Ithaca: Cornell University.

Anigbo, C. A., \& Eze, O. C. (2010). New Scramble for Africa. Lagos: N.I.I.A.

Ayandele, E. A. (1966). The Maghreb in the Nineteenth Century. In J. C., Anene, \& Brown, G. N. (Eds.), Africa in the $19^{\text {th }} \& 20^{\text {th }}$ Century. Ibadan: University Press.

Cabral, A. (1966). Weapon of Theory. Havana.

Enor, F. (2012). US Policy Towards Africa since the Cold War. Calabar: Saes Print Publishers.

Gerard, C. (1975). Revolution in the Third World: Myths \& Prospects. Hassodes, Sussex: The Harvester Press.

Gurley, J. G. (1988). Challenges to Capitalism: Marx, Lenin, Stalin and Mao. New York: Addison Wesley Publishing Company Inc.

Heinecke, P. (1986). Freedom in the Grave: Nigeria and the Political Economy of Africa (4th ed.). Okpella-Nigeria: S. Asekome \& Co. Publishers.

Kimmel, M. S. (1990). Revolution: A Sociological Interpretation. Oxford: Oxford Polity Press.

Kolko, G. (1988). Confronting the Third World: US Foreign Policy, 1945-1980. New York: Panthem Publishers.

Mazrui, A. (1977). Africa's International Relations: The Diplomacy of Dependence and Change. http://dx.doi.org/10.1017/s0022278x00005231

Molineu, H (1986). US Policy toward Latin America from Regionalism to Globalism. Boulder: Westview Press Inc.

Rothchild, D., \& Keller, J. E. (2006). Africa-US Relations: Strategic Encounters. USA West view Press Inc.

Wilmot, P. (1980). Ideology and National Consciousnes. Ibadan: Lantern Books. 